\title{
PROBLEM NIEWOLNICTWA W STANACH ZJEDNOCZONYCH PRZEŁOMU XVIII I XIX WIEKU W RELACJACH JULIANA URSYNA NIEMCEWICZA Z PODRÓŻY PO AMERYCE
}

\begin{abstract}
Streszczenie. Julian Ursyn Niemcewicz, polski pisarz i polityk, odbył w latach 1797-1807 dwie podróże po Stanach Zjednoczonych. Pokłosiem jego pobytu za oceanem są obszerne dzienniki, w których na bieżąco notował swoje przeżycia, obserwacje i spostrzeżenia na temat tego kraju. Niemcewicz, zwiedzając Stany Zjednoczone, zachwycał się tym państwem, które uważał za urzeczywistnienie oświeceniowych idei równości i wolności. Z drugiej strony, podczas pobytu w Ameryce polski podróżnik zetknął się także z problemem niewolnictwa. W trakcie pobytu w Virginii - jedynym stanie należącym do „Południa”, który odwiedził - szczegółowo opisywał warunki życia niewolników i sposób ich traktowania. Podjął również refleksję nad przyczynami istnienia i utrzymywania niewolnictwa w południowej części USA. Celem artykułu jest analiza sposobu postrzegania niewolnictwa przez Niemcewicza na podstawie jego dzienników, w jaki sposób poglądy Niemcewicza wobec niewolnictwa odzwierciedlają kontekst epoki oraz czy i w jakim stopniu fakt istnienia systemu niewolniczego wywarł wpływ na stosunek pisarza do Stanów Zjednoczonych.
\end{abstract}

Słowa kluczowe: Julian Ursyn Niemcewicz, Ameryka, Stany Zjednoczone, podróże, dzienniki, niewolnictwo, XVIII-XIX wiek.

\section{Julian Ursyn Niemcewicz i jego pobyt w Ameryce}

tany Zjednoczone, w momencie rozpoczęcia przez mieszkańców brytyjskich kolonii walki o niepodległość, a potem już jako niepodległe państwo, fascynowały Europejczyków. Rewolucja amerykańska (1775-1783) była jednym z impulsów do przewrotu we Francji, a tym samym 
zainspirowała wielkie przemiany na Starym Kontynencie. Nowy kraj zza oceanu szybko stał się symbolem wolności, równości, państwem, które wcieliło w życie ideały oświecenia. Wydarzeniami w Ameryce Północnej interesowali się również Polacy. Powstanie Stanów Zjednoczonych zbiegło się z przemianami w Rzeczpospolitej. Wątki amerykańskie były stale obecne w polskiej publicystyce politycznej ostatnich dekad XVIII w. i stanowiły istotny element argumentacji za lub przeciw przemianom ustrojowym w Rzeczpospolitej oraz w dyskusji nad ich kształtem. Ówczesna elita społeczeństwa polskiego wyrażała żywe zainteresowanie amerykańską wojną o niepodległość oraz nowopowstałym państwem.

W tym świetle nie dziwi fascynacja Ameryką, jaką przejawiał polski pisarz i polityk, Julian Ursyn Niemcewicz (1757-1841). Pochodzący ze średniozamożnej rodziny szlachcic, dzięki protekcji Adama Kazimierza Czartoryskiego już w młodości dużo podróżował, zwiedzając m.in. Włochy, Francję, Anglię, Holandię, Niemcy i Austrię ${ }^{1}$. To właśnie podczas pobytu w Paryżu w 1787 r. po raz pierwszy zetknął się z „Ameryką", poznając osobiście Thomasa Jeffersona, przyszłego prezydenta USA ${ }^{2}$, a także Filippa Mazzeiego, uczestnika wojny o niepodległość Stanów Zjednoczonych, bliskiego znajomego czołowych amerykańskich polityków3 ${ }^{3}$. Uczestnicząc w obradach Sejmu Czteroletniego, był jednym z tych posłów, którzy uzasadniali konieczność wprowadzenia reform społeczno-ustrojowych w Polsce odwołaniem do wzorców amerykańskich. W kwietniu 1791 r., wygłaszając przemówienie nawołujące do przyznaniem praw chłopom i mieszczanom, powiedział:

[...] częstokroć ludzie, których my nazywamy bez urodzenia, ratowali, wysławiali ojczyznę swoją. Nikt nie wie, czym był ojciec Waszyngtona, ani kogo Franklin dziadem swym liczył, ale każdy wie i potomność wiedzieć będzie, że Waszyngton i Franklin oswobodzili Amerykę .

Przywódcy amerykańskiej rewolucji posłużyli mu za przykład ludzi wybitnych i wyjątkowych, którzy zapisali się w historii niezależnie od ich pochodzenia. W latach 1791-1792 Niemcewicz współredagował pismo polityczne, „Gazetę Narodową i Obcą", na łamach której publikowano wieści o wydarzeniach w Stanach Zjednoczonych, będących dla środowiska „pa-

${ }^{1}$ W. Bolecki, Julian Ursyn Niemcewicz, [w:] Pisarze polskiego oświecenia, t. 2, red. Z. Goliński, T. Kostkiewiczowa, Warszawa 1994, s. 388.

2 M. Drozdowski, Rewolucja amerykańska w polskiej myśli historycznej $w$ historiografii i publicystyce 1776-1976, Warszawa 1976, s. 43.

${ }^{3}$ E. Jeglińska, Między marzeniem a rzeczywistością. Ameryka w twórczości Juliana Ursyna Niemcewicza, Poznań 2010, s. 23.

${ }^{4}$ Cyt. za W. Bolecki, op. cit., s. 392. 
triotów" przykładem sukcesu ideałów równości i wolności, które przyświecały również polskim reformatorom ${ }^{5}$.

Już kilka lat później miał możliwość skonfrontowania swoich wyobrażeń i opinii na temat Stanów Zjednoczonych z rzeczywistością. Po upadku insurekcji kościuszkowskiej (w której pełnił funkcję adiutanta przywódcy) i blisko dwuletnim pobycie w petersburskim więzieniu, na prośbę Tadeusza Kościuszki Niemcewicz zdecydował się towarzyszyć mu w podróży do Stanów Zjednoczonych. Po długiej podróży przez Europę i kilkudziesięciu dniach rejsu przez ocean, w sierpniu 1797 r. dotarli do Filadelfii.

Pierwsze 2 lata pobytu Juliana Ursyna Niemcewicza w Ameryce upłynęły mu przede wszystkim na odwiedzinach u znajomych i przyjaciół Kościuszki, który nadal cieszył się bardzo dużą popularnością w Stanach Zjednoczonych. Dzięki niemu Niemcewicz poznał kilku amerykańskich dowódców z czasów wojny o niepodległość, a także najważniejszych polityków, na czele z prezydentem Johnem Adamsem ${ }^{6}$. Liczne spotkania pozwoliły mu poznać z bliska stosunki społeczne i życie codzienne wyższych sfer. Ze względu na zły stan zdrowia Kościuszki, to właśnie Niemcewicz odpowiadał za aprowizację i organizację wyjazdów, pomagał również byłemu naczelnikowi powstania w załatwianiu niektórych spraw ${ }^{7}$. Okazał się człowiekiem bardzo otwartym i towarzyskim, co pozwoliło mu na nawiązanie nowych znajomości. Zwiedził wiele miast i miasteczek na terenie stanów Massachusetts, New Jersey, New York i Pensylwanii - przede wszystkim największe wówczas ośrodki miejskie, czyli Boston, Filadelfię i Nowy Jork.

W maju 1798 r. Tadeusz Kościuszko zdecydował się wyjechać do Francji, o czym poinformował Niemcewicza dopiero na dzień przed wyjazdem, polecając mu pozostanie w $\mathrm{USA}^{8}$. Nagła decyzja towarzysza podróży zaskoczyła i rozczarowała Niemcewicza, który znalazł się w trudnej sytuacji, spowodowanej brakiem środków do życia9. Ostatecznie Niemcewicz pożyczył pieniądze od Tomasza Jeffersona i rozpoczął zwiedzanie kraju, o czym wcześniej marzy $\mathfrak{1}^{10}$. Wyruszył na południe, gdzie kilka tygodni później poznał osobiście byłego prezydenta Stanów Zjednoczonych, Jerzego Waszyngtona. Nawiązane wcześniej kontakty umożliwiły mu dalszą podróż - wrócił na

${ }^{5}$ Ibidem, s. 303.

${ }^{6}$ J.U. Niemcewicz, Podróże po Ameryce 1797-1807, wstęp i oprac. A. Wellman-Zalewska, Warszawa 1959, s. 66-67.

7 I. Rusinowa, Pana Juliana przypadki życia. Julian Ursyn Niemcewicz 1797-1841, Warszawa 1999 , s. 26.

${ }^{8}$ J.U. Niemcewicz, Podróże po Ameryce..., s. 108.

${ }^{9}$ Ibidem, s. 109.

10 Idem, Pamiętniki czasów moich, t. 2, wstęp i oprac. J. Dihm, Warszawa 1957, s. 225. 
północ inną drogą, zwiedzając wnętrze kraju ${ }^{11}$. Następnie zamieszkał w Elisabeth Town w New Jersey, gdzie w 1800 r. ożenił się z Amerykanką, Zuzanną (Susan) Livingston-Kean, wdową po generale Johnie Kean, przyjacielu Tadeusza Kościuszki. Nie mając, nad czym po latach ubolewał, przygotowania do żadnego konkretnego zawodu, postanowił zająć się ogrodnictwem. Poza tym uczył swojego pasierba, dziesięcioletniego Petera, łaciny, francuskiego i innych przedmiotów ${ }^{12}$. W 1802 r. otrzymał wiadomość o śmierci ojca i wyjechał do Polski, by uregulować sprawy majątkowe. Po dwóch latach wrócił do Ameryki. Podczas drugiego pobytu w Stanach Zjednoczonych rzadziej podróżował - najważniejszym wydarzeniem z tego okresu była wyprawa do wodospadu Niagara, którą odbył w towarzystwie przyjaciół w październiku 1805 r. Podczas drogi przez północną część stanu Nowy Jork poznał mniej „cywilizowaną” część Stanów Zjednoczonych. Po powrocie z wycieczki prowadził spokojne, jednostajne życie ziemianina, przerywane od czasu do czasu odwiedzinami u znajomych. Próbował też kontynuować twórczość literacką ${ }^{13}$. W 1805 r. przyjął amerykańskie obywatelstwo, co świadczyło o tym, że planował zostać w Stanach Zjednoczonych już na stałe. Jego fascynację tamtejszą rzeczywistością przyćmiły jednak tęsknota za ojczyzną i problemy osobiste. Kilkukrotnie wspominał o trudnych relacjach z często chorą żoną i smutku z powodu braku polskiego towarzystwa - uważał, że gdyby było inaczej, Ameryka stałaby się dla niego miłym, rozsq̨dnym i nie ogołoconym z przyjemności schronieniem ${ }^{14}$. Dlatego też wiosną 1807 r., na wieść o sukcesach Napoleona i jego wkroczeniu na ziemie polskie, widząc nadzieję na odzyskanie niepodległości przez ojczyznę, zdecydował się na wyjazd do Polski. Już nigdy więcej nie wrócił do Stanów Zjednoczonych.

\section{Okoliczności powstania i wydania źródeł}

Pokłosiem pobytu Niemcewicza za oceanem są obszerne dzienniki, w których notował swoje przeżycia, obserwacje i spostrzeżenia na temat tego kraju. Charakterystyczną cechą relacji Niemcewicza jest bardzo szeroki zakres zainteresowań - przedstawiając Amerykę, opisywał właściwie wszystko - począwszy od wielkiej polityki (bywał na posiedzeniach Kongresu, poznał osobiście najważniejsze postaci życia publicznego), przez społeczeństwo, mniejszości narodowe, wyznaniowe i etniczne, charakterystykę miast, miasteczek i znajdujących się w nich instytucji, aż po krajobraz i przyrodę.

11 I. Rusinowa, op. cit., s. 42.

12 J.U. Niemcewicz, Pamiętniki czasów moich..., s. 239-240.

${ }^{13}$ M. Nalepa, Literacki plon pobytów Juliana Ursyna Niemcewicza w Ameryce, [w:] Julian Ursyn Niemcewicz: pisarz, historyk, świadek epoki, red. J. Wójcicki, Warszawa 2002, s. 89-90.

14 J.U. Niemcewicz, Podróże po Ameryce..., s. 377. 
Niemcewicz często spisywał swoje przeżycia i obserwacje na bieżąco, w trakcie podróży, o czym miał świadczyć niestaranny charakter pisma ${ }^{15}$. Dzienniki podróży po Stanach Zjednoczonych miały charakter prywatnych notatek, przeznaczonych wyłącznie dla samego Niemcewicza i nie były przeznaczone do upublicznienia $\mathrm{w}$ takim kształcie ${ }^{16}$. Można przypuszczać, że planował po latach uczynić je podstawą swojej autobiografii, ponieważ od końca lat dwudziestych XIX w. zaczął spisywać swoje wspomnienia, obejmujące okres od dzieciństwa aż do czasów mu współczesnych. Tak się jednak nie stało - gdy po upadku powstania listopadowego udał się na przymusową emigrację do Paryża, dzienniki prowadzone w Stanach Zjednoczonych pozostawił w Polsce, uważając je za bezpowrotnie stracone, nad czym ubolewał w swoich pamiętnikach ${ }^{17}$.

Dziennik drugiej podróży Niemcewicza po Ameryce (1804-1807) został po raz pierwszy wydany drukiem w 1873 r. przez Zakład Naukowy im. Ossolińskich we Lwowie. Autor edycji, jak twierdzi w przedmowie, wszedł w posiadanie kopii rękopisu „szczęśliwym zbiegiem okoliczności”"18. Wydanie, wbrew temu, co wskazuje jego tytuł, obejmuje lata 1802-1807 - czyli także okres pobytu Niemcewicza w Polsce i podróż powrotną do Stanów Zjednoczonych. Zdaniem Antoniny Wellman-Zalewskiej, wydarzenia z lat 1802-1804 Niemcewicz mógł opisać już po powrocie do Ameryki ${ }^{19}$. Z kolei zapiski Niemcewicza z pierwszego pobytu w USA znacznie dłużej pozostawały nieznane szerszemu odbiorcy. Wzmianki o dzienniku pierwszej podróży Niemcewicza do Ameryki, obejmującym lata 1797-1799, pojawiły się bowiem w literaturze naukowej dopiero na początku XX w. Rękopis, przechowywany w Bibliotece Ordynacji Zamoyskich w Warszawie, jako pierwszy odnalazł historyk Władysław Kozłowski. Na jego podstawie podjął próbę analizy okoliczności pobytu Niemcewicza i Kościuszki w Stanach Zjednoczonych, przytaczając pisane przez nich listy i fragment dziennika ${ }^{20}$. Poza

15 Wstęp, [w:] J.U. Niemcewicz, Podróże po Ameryce..., s. IX.

${ }_{16}$ Świadczy o tym uwaga, którą zanotował w Dzienniku drugiej podróży do Ameryki na temat swojej wycieczki do Niagary. Stwierdził, że największą trudnością w zorganizowaniu tego wyjazdu było uzyskanie pozwolenia małżonki. Dodał, że na szczęście piszę jedynie dla siebie lub może dla jednego jeszcze przyjaciela, obawiając się, że mógłby ośmieszyć się przed czytelnikami, sprawiając wrażenie człowieka podporządkowanego żonie i uzależnionego od jej decyzji, por. Ibidem, s. 378.

17 Idem, Pamiętniki czasów moich..., s. 225.

18 Pamiętniki Juliana Ursyna Niemcewicza, 1804-1807. Dziennik drugiej podróży do Ameryki, Lwów 1873, s. VI.

${ }^{19}$ Wstęp, [w:] J.U. Niemcewicz, Podróże po Ameryce..., s. XXIV.

${ }^{20}$ W. Kozłowski, Pobyt Kościuszki i Niemcewicza w latach 1797 i 1798, „Biblioteka Warszawska" 1906, t. IV, s. 241-284; idem, Rozstanie się Kościuszki i Niemcewicza w Filadelfii, „Kwartalnik Historyczny” 1906, R. 20, s. 225-252. 
tym przetłumaczył na język angielski i opublikował w amerykańskim piśmie relację Niemcewicza ze spotkania z Jerzym Waszyngtonem ${ }^{21}$. Kozłowski odnalazł także dziennik podróży Niemcewicza do Niagary z $1805 \mathrm{r}^{22} \mathrm{Nie}-$ stety wówczas nikt więcej nie zainteresował się tym tematem i nie podjął próby wydania rękopisu drukiem ani nawet odnalezienia wszystkich amerykańskich zapisków Niemcewicza z lat 1797-1802. W 1931 r. badacz historii amerykańskiej Polonii, Mieczysław Haiman postulował opublikowanie wszystkich relacji Niemcewicza dotyczących Ameryki (i przetłumaczenie ich na język angielski) ze względu na wielką wartość tych źródeł dla polskiej emigracji i jej dziejów ${ }^{23}$. Apel ten pozostał bez odzewu aż do wydania edycji będącej podstawą źródłową niniejszej pracy.

Edycja opracowana w 1959 r. przez Antoninę Wellman-Zalewską jest zatem pierwszym wydawnictwem źródłowym obejmującym wszystkie obecnie dostępne i znane badaczom dzienniki Niemcewicza z „amerykańskiego" okresu jego życia - tj. zapiski z podróży z Petersburga do Szwecji (1796-1797), Dziennik pierwszej podróży do Ameryki (1797-1799), Dziennik drugiej podróży do Ameryki (1802-1807) ${ }^{24}$ oraz Dziennik podróży do Niagary (1805). Dotychczas nie odnaleziono części opisu pobytu w Szwecji, Anglii, podróży morskiej do Ameryki oraz pierwszych dni w Stanach Zjednoczonych; zaginął także Diariusz żeglugi pięciotygodniowej od 4 lipca do 8 sierpnia 1802 z Ameryki do Europy ${ }^{25}$.

\section{Stany Zjednoczone pod koniec XVIII w. Niewolnictwo oczami Niemcewicza}

W momencie przyjazdu Niemcewicza, Stany Zjednoczone istniały jako niepodległy kraj dopiero od kilkunastu lat i w dalszym ciągu przechodziły etap formowania się pod względem politycznym, ideowym i terytorialnym. Mieszkańcy 13 założycielskich stanów rozpoczęli ekspansję na tereny położone na zachód od „Nowej Anglii”. W latach dziewięćdziesiątych XVIII w. do federacji przyłączyły się trzy kolejne stany: Vermont (1791), Kentucky (1792) i Tennessee (1796). Państwo liczyło w tym okresie około 4 mln mieszkańców. Najważniejszymi miastami były Filadelfia i Boston, inne późniejsze metropolie

${ }^{21}$ Idem, A visit to Mount Vernon a Century Ago, „Century Magazine” February 1902, s. 510-522.

${ }^{22}$ Wstęp, [w:] J.U. Niemcewicz, Podróże po Ameryce..., s. XXIV. Dziennik podróży do Niagary został opublikowany w: W. Kozłowski, Niemcewicz u Niagary (z nie wydanego [sic!] pamiętnika J.U. Niemcewicza), „Bluszcz” 1917, nr 28-29.

${ }^{23}$ L. Pastusiak, Pierwsi polscy podróżnicy w Stanach Zjednoczonych, Warszawa 1980, s. 177.

${ }^{24}$ Edycja Wellman-Zalewskiej przedrukowuje w całości wydanie Dziennika drugiej podróży... z 1873 r., por. Wstęp, [w:] J.U. Niemcewicz, Podróże po Ameryce..., s. XXIII.

${ }^{25} \mathrm{O}$ jego możliwym istnieniu wspomina M. Nalepa, op. cit., s. 89. 
- Waszyngton, Baltimore i Nowy Jork - wówczas jeszcze niewielkie, znajdowały się w fazie intensywnego rozwoju. Z niewielkich osad przekształcały się powoli w tętniące życiem ośrodki ${ }^{26}$.

Julian Ursyn Niemcewicz dostrzegał i chwalił amerykański postęp cywilizacyjny, a Stany Zjednoczone uważał za urzeczywistnienie bliskich mu ideałów wolności i równości. Cieniem na pozytywnym wizerunku Ameryki, który wyłania się z relacji Niemcewicza, kładzie się sytuacja ludności kolorowej w USA - Indian, a przede wszystkim czarnoskórych niewolników.

Początki niewolnictwa na terenie Stanów Zjednoczonych miały miejsce już w czasach, gdy obszar ten był pod panowaniem brytyjskim - już w XVII w. powstawały pierwsze plantacje, oparte na pracy sprowadzonych z Afryki niewolników. Rewolucja amerykańska po części przyniosła zmianę położenia ludności czarnoskórej. Leżące u jej podstaw hasła powszechnej równości doprowadziły do emancypacji niewolników - jednak wyłącznie w północnej części Nowej Anglii, gdzie liczba niewolników była niewielka ${ }^{27}$. W Delaware już w 1776 r. wprowadzono zakaz importu i sprzedaży niewolników na terenie całego stanu. W 1783 r. emancypację niewolników uchwalono w Massachusetts, a w ślad za nim poszły w kolejnych latach inne stany - aż w $1787 \mathrm{r}$. amerykański Kongres uchwalił zakaz niewolnictwa w stanach północnych i północno-zachodnich. Jednak w południowej części kraju, gdzie żyło o wiele więcej czarnoskórej ludności, a gospodarka była de facto uzależniona od ich niewolniczej pracy, właściciele plantacji stanowczo i skutecznie opowiadali się przeciwko likwidacji niewolnictwa ${ }^{28}$.

Jedynym stanem, zaliczanym do amerykańskiego Południa, który odwiedził Julian Ursyn Niemcewicz, była Wirginia. Zaobserwował tam wiele przykładów nieludzkiego traktowania niewolników. Widział ich podczas pracy przy uprawie kukurydzy, wychudzonych i odzianych w łachmany ${ }^{29}$. Spotkał się z przypadkiem torturowania Murzynów ${ }^{30}$ oraz traktowaniem ich niemalże jak zwierzęta ${ }^{31}$. Podczas pobytu w rezydencji Jerzego Waszyngtona, który również posiadał liczną grupę niewolników, miał okazję zobaczyć lepianki służące im za mieszkania. Oceniał je jako nędzne i prymitywne.

${ }^{26}$ I. Grudzińska-Gross, „Jedź do Francji, jedź do Europy”. Niemcewicz i Ameryka, [w:] Julian Ursyn Niemcewicz: pisarz, historyk, świadek epoki, red. J. Wójcicki, Warszawa 2002, s. 83.

${ }^{27}$ I. Berlin, Pokolenia $w$ niewoli. Historia niewolnictwa $w$ Ameryce Północnej, Warszawa 2010, s. 106.

${ }^{28}$ Ibidem, s. 107.

${ }^{29}$ J.U. Niemcewicz, Podróże po Ameryce..., s. 135.

30 Ibidem, s. 162.

${ }^{31}$ Dwie mile dalej wysiadł [...] pan ze swoim Murzynem. Miał on siodło, które włożył mu na plecy; myślałem, że będzie na nim jechał, ale zadowolił się zarzuceniem mu uzdy na szyję i prowadził go za sobq jak konia. [...] Bóg wie, jaki los czeka biednego Murzyna. Por. Ibidem, s. 114. 
Co warte odnotowania, sam fakt posiadania niewolników przez Waszyngtona nie zmienił pozytywnej opinii Niemcewicza o byłym prezydencie. Jego zdaniem, generał i tak traktował swoich Murzynów lepiej niż inni właściciele z Wirginii - przede wszystkim lepiej ich odżywiano ${ }^{32}$. Nie była to jednak próba usprawiedliwienia Waszyngtona. W porównaniu z tym, co wcześniej usłyszał na temat sytuacji niewolników w tym stanie, można ocenić, że jego opinia była jak najbardziej słuszna ${ }^{33}$.

Porównując sytuację amerykańskich niewolników i polskich chłopów, stwierdził, że położenie tych pierwszych było o wiele gorsze ${ }^{34}$. Nie dziwiło go zatem, gdy słyszał od swoich rozmówców o częstych ucieczkach niewolników od swoich właścicieli. Pomocy w tych próbach odzyskania wolności udzielali najczęściej kwakrzy, którzy uważali instytucję niewolnictwa za sprzeczną z zasadami chrześcijaństwa i najaktywniej działali na rzecz jego zniesienia $^{35}$. Dlatego też, o czym pisał Niemcewicz, miejscem, do którego przeważnie udawali się zbiegli niewolnicy, była Filadelfia ${ }^{36}$ (i ogólnie stan Pensylwania) - gdzie sekta kwakrów miała najwięcej członków. Niemcewicz zdawał się popierać proceder zbiegostwa Murzynów. Gdy podczas pobytu w Charlestown usłyszał o próbie uwolnienia niewolnika z kajdan pod osłoną nocy, zastanawiał się, kto mógł być tym litościwym człowiekiem, który chciał uwolnić biedna ofiarę $e^{37}$.

Wypowiedzi Niemcewicza na temat niewolników nie są przesadnie emocjonalne. Był oświeceniowym racjonalistą i tak też starał się oceniać rzeczywistość, kierując się rozsądną analizą. Widać jednak, że im współczuł, a stosowanie wobec nich okrucieństwa uważał za nieludzkie i niepotrzebne. Cieszył się z faktu, że przynajmniej niewolnicy pracujący jako służba domowa, byli traktowani łagodniej, często niemalże jak członkowie rodziny $^{38}$. W przeciwieństwie do wielu Amerykanów, uprzedzonych wobec czarnych $^{39}$, nie uważał Murzynów za „podludzi”. Stwierdził, że niewolnicy, nawet dobrze traktowani, nigdy nie będą szczęśliwi, ponieważ pragnienie

${ }^{32}$ Ibidem, s. 150.

${ }^{33}$ Położenie niewolników $w$ Wirginii jest według jego sprawozdania [tj. farmera z hrabstwa Barckley - przyp. MK], bardzo ciężkie. Jako pożywienie dostają tylko chleb i wodę, czasami mleko. Właściciele żyją przeważnie z Murzynkami, a dzieci z tych związków sq niewolnikami i w tym charakterze dostają się dzieciom właścicieli, por. Ibidem, s. 138.

34 Ibidem, s. 149-150.

${ }^{35}$ R. Middlekauff, Rewolucja amerykańska, [w:] Historia Stanów Zjednoczonych Ameryki, t. 2 (1763-1848), red. B. Sheehan, I. Wawrzyczek, Warszawa 1995, s. 27.

${ }^{36}$ J.U. Niemcewicz, Podróże po Ameryce..., s. 112.

37 Ibidem, s. 114.

38 Ibidem, s. 247.

39 R. Middlekauff, Rewolucja amerykańska..., s. 26. 
wolności jest wrodzoną cechą człowieka ${ }^{40}$. Należy też zaznaczyć, że w odróżnieniu od Indian, nie określał Murzynów jako dzikich, których należałoby ucywilizować. Stąd niektórzy wysnuwali wniosek, że uważał ich za integralną część społeczeństwa amerykańskiego, inaczej niż Indian, pozostających poza nim ${ }^{41}$. Siłą rzeczy niewolnicy, pracując u białych i mieszkając w ich posiadłościach byli bliżej „cywilizacji” niż rdzenni mieszkańcy Ameryki, których odrębność była o wiele bardziej widoczna.

W dziennikach Niemcewicza można również odnaleźć próbę analizy przyczyny występowania i utrzymywania systemu niewolniczego. W relacji z pobytu w Mount Vernon, Niemcewicz przytoczył interesującą rozmowę, którą odbył na temat niewolnictwa z niejakim doktorem Stuartem. Przytacza jego opinię, że posiadanie niewolników jest okrutne i - ze względu wysokich kosztów ich utrzymania i nadzoru - przede wszystkim nieopłacalne, z czego właściciele ziemscy w Wirginii doskonale zdawali sobie sprawę. Jednak nie mogli zrezygnować z wykorzystywania Murzynów, z jednej strony z powodu silnie zakorzenionego przekonania o niższości ich rasy, z drugiej - ponieważ brakowało rąk do pracy na plantacjach ${ }^{42}$. Niemcewicz zgadzał się z taką oceną sytuacji. Jego zdaniem problem mogła rozwiązać jeszcze większa imigracja białych, których było zbyt mało w stosunku do wielkości kraju i posiadłości ziemskich, dlatego musieli utrzymywać niewolników - szczególnie na Południu, którego gospodarka była oparta na uprawie tytoniu i bawełny ${ }^{43}$. Ironicznie stwierdził, że w Wirginii ciężar pracy zwalony jest na Murzynów, a ciężar próżnowania zostawiony białym ${ }^{44}$. Uważał zatem niewolnictwo nie tylko za coś nieludzkiego, ale także niewydajnego pod kątem gospodarczym. Dostrzegał, że głodzenie i bicie niewolników znacznie obniża jakość ich pracy. Łagodniejsze traktowanie Murzynów było według niego o wiele korzystniejsze dla właścicieli ${ }^{45}$.

\section{Podsumowanie}

Czy zetknięcie z niewolnictwem i sposobem traktowania Murzynów miało wpływ na sposób postrzegania Ameryki przez Niemcewicza? Z jednej strony, podobnie jak inni europejscy podróżnicy, dostrzegał kontrast i sprzeczność

40 J.U. Niemcewicz, Podróże po Ameryce..., s. 374.

${ }^{41}$ M. Drozdowski, Z dziejów stosunków polsko-amerykańskich 1776-1944, Warszawa 1982, s. 43.

${ }^{42}$ J.U. Niemcewicz, Podróże po Ameryce..., s. 153.

43 Ibidem, s. 154.

${ }^{44}$ Ibidem, s. 170.

45 Ibidem, s. 247. 
pomiędzy wolnością amerykańskich obywateli amerykańskich a niewolnictwem Murzynów i ich trudnym położeniem ${ }^{46}$. Gdy zwiedzając więzienie w Elisabeth Town dowiedział się, że schwytani zbiegli niewolnicy będą sądzeni wyłącznie przez swoich panów, zareagował z oburzeniem. Dziwiło go takie rozwiązanie w państwie, które szczyciło się demokracją i praworządnością ${ }^{47}$. Podobnie ocenił sytuację w Georgetown, gdzie odnotował, że chociaż tamtejsi Murzyni otrzymywali wynagrodzenie za swoją pracę na rzecz miasta, musieli oddać je w całości swoim właścicielom. Niemcewicz, opisując zdarzenie, retorycznie pytał: Gdzież to ludzkość? Jakiż to kraj wolności? ${ }^{48}$.

Niemcewicz, choć poruszony losem niewolników, zdawał sobie sprawę, że nierówne traktowanie ras były nieodłączną cechą świata, w którym żył. W Stanach Zjednoczonych, szczególnie na Południu, niewolnictwo stało się nienaruszalnym elementem stosunków społecznych ${ }^{49}$. Ruch działający na rzecz jego zniesienia w czasach pobytu Niemcewicza nie był jeszcze zbyt liczny. Niemcewicz dostrzegał i rozumiał specyfikę kraju, w którym się znalazł. Notabene, w majątku jego żony w Elisabeth Town również pracowali niewolnicy. Nie pisał zbyt wiele o ich traktowaniu, natomiast zdarzyło mu

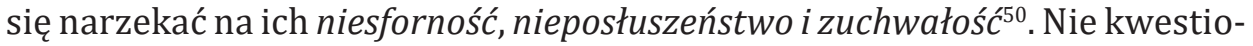
nował zatem samego faktu istnienia niewolnictwa i nie deklarował się jako zwolennik jego zniesienia. Chociaż nie akceptował okrucieństwa i dostrzegał wady systemu niewolniczego, nie reagował na nie, w tym przypadku pozostając jedynie biernym obserwatorem. Widząc nieludzkie traktowanie niewolników, zdawał sobie sprawę ze sprzeczności niewolnictwa z wizją Stanów Zjednoczonych jako kraju wolności i równości. Jednak fakt jego istnienia nie wpłynął w sposób znaczący na ogólną pozytywną opinię, jaką posiadał na temat tego kraju. Należy bowiem pamiętać, że Niemcewicz był w pełni „człowiekiem swojej epoki”, której integralną częścią było istnienie niewolnictwa i nierówności społecznych.

${ }^{46}$ I. Grudzińska-Gross, op. cit., s. 85.

47 J.U. Niemcewicz, Podróże po Ameryce..., s. 60.

48 Ibidem, s. 141.

49 I. Wawrzyczek, System niewolniczy brytyjskiej Ameryki, [w:] Historia Stanów Zjednoczonych, t. 1 (1607-1763), red. M. Rozbicki, I. Wawrzyczek, Warszawa 1995, s. 139.

${ }^{50}$ J.U. Niemcewicz, Podróże po Ameryce..., s. 376. 


\section{BIBLIOGRAFIA}

\section{Źródła}

Niemcewicz J.U., Pamiętniki czasów moich, t. II, wstęp i oprac. J. Dihm, Warszawa 1957.

Niemcewicz J.U., Pamiętniki Juliana Ursyna Niemcewicza, 1804-1807. Dziennik drugiej podróży do Ameryki, Lwów 1873.

Niemcewicz J.U., Podróże po Ameryce 1797-1807, wstęp i oprac. A. Wellman-Zalewska, Warszawa 1959.

\section{Opracowania}

Berlin I., Pokolenia w niewoli. Historia niewolnictwa w Ameryce Północnej, Warszawa 2010, s. 106.

Bolecki W., Julian Ursyn Niemcewicz, [w:] Pisarze polskiego oświecenia, t. 2, red. Z. Goliński, T. Kostkiewiczowa, Warszawa 1994, s. 388-390.

Drozdowski M., Rewolucja amerykańska w polskiej myśli historycznej w historiografii i publicystyce 1776-1976, Warszawa 1976.

Drozdowski M., Z dziejów stosunków polsko-amerykańskich 1776-1944, Warszawa 1982.

Grudzińska-Gross I., „Jedź do Francji, jedź do Europy”. Niemcewicz i Ameryka, [w:] Julian Ursyn Niemcewicz: pisarz, historyk, świadek epoki, red. J. Wójcicki, Warszawa 2002, s. 81-88.

Jeglińska E., Między marzeniem a rzeczywistością. Ameryka w twórczości Juliana Ursyna Niemcewicza, Poznań 2010.

Kozłowski W., A visit to Mount Vernon a Century Ago, „Century Magazine”, February 1902, s. 510-522.

Kozłowski W., Niemcewicz u Niagary (z nie wydanego [sic!] pamiętnika J.U. Niemcewicza), „Bluszcz” 1917, nr 28-29.

Kozłowski W., Pobyt Kościuszki i Niemcewicza w latach 1797 i 1798, „Biblioteka Warszawska” 1906, t. 4, s. 241-284.

Kozłowski W., Rozstanie się Kościuszki i Niemcewicza w Filadelfii, „Kwartalnik Historyczny” 1906, R. 20, s. 225-252.

Middlekauff R., Rewolucja amerykańska, [w:] Historia Stanów Zjednoczonych Ameryki, t. 2 (1763-1848), red. B. Sheehan, I. Wawrzyczek, Warszawa 1995, s. 7-29.

Nalepa M., Literacki plon pobytów Juliana Ursyna Niemcewicza w Ameryce, [w:] Julian Ursyn Niemcewicz: pisarz, historyk, świadek epoki, red. J. Wójcicki, Warszawa 2002, s. 89-99.

Pastusiak L., Pierwsi polscy podróżnicy w Stanach Zjednoczonych, Warszawa 1980.

Rusinowa I., Pana Juliana przypadki życia. Julian Ursyn Niemcewicz 1797-1841, Warszawa 1999.

Wawrzyczek I., System niewolniczy brytyjskiej Ameryki, [w:] Historia Stanów Zjednoczonych, t. 1 (1607-1763), red. M. Rozbicki, I. Wawrzyczek, Warszawa 1995, s. 137-166. 


\title{
Monika Kaniecka
}

\section{SLAVERY IN THE $18^{\text {TH }}-19^{\text {TH }}$ CENTURY UNITED STATES IN JULIAN URSYN NIEMCEWICZ'S RELATIONS FROM TRAVELS THROUGH AMERICA}

\begin{abstract}
I ulian Ursyn Niemcewicz, Polish writer and politician, in 1797-1807 travelled to the United States twice. During that time he wrote a few comprehensive journals, which described his experiences, observations and opinions about that country. Niemcewicz, while visiting the USA, was delighted about the state, that reminded him the ideals of equality and freedom. However, during the journey he encountered the issue of slavery. During the stay in Virginia - the only south state he visited - Niemcewicz described in details the living conditions of slaves and the way they were treated by their owners. Moreover, he tried to study the possible causes of slavery in the southern parts of the USA. The aim of the article is to analyze the way Niemcewicz perceived slavery, in which way this views reflected the context of epoque and how the existence of slavery influenced his vision of America.
\end{abstract}

Keywords: Julian Ursyn Niemcewicz, America, the United States, travels, journals, slavery, $18^{\text {th }}-19^{\text {th }}$ century. 